\title{
ASSESSMENT OF MORPHOLOGICAL DIVERSITY AMONG FULL SIBS OF SWEETPOTATO (Ipomoea batatas (L.) Lam) GENOTYPES IN UMUDIKE, SOUTHEASTERN NIGERIA
}

\author{
${ }^{1}$ ULASI, J. I., ${ }^{2}$ AFUAPE S. O. and ${ }^{3}$ KEYAGHA E. R. \\ ${ }^{1}$ Department of Crop Science, Faculty of Agriculture, University of Uyo, \\ 1P.M.B 1017, Uyo, Akwa, Ibom State. \\ ${ }^{2}$ National Root Crops Research Institute (NRCRI), Umudike, P.M.B. 7006, Umuahia Abia State, Nigeria \\ ${ }^{3}$ Department of Crop Science and Technology, Federal University of Technology, \\ ${ }^{3}$ P.M.B. 1526, Owerri, Imo State \\ https://doi.org/10.35410/IJAEB.2021.5684
}

\begin{abstract}
Identification of diversity among germplasm collections is a prerequisite to select parents with favourable traits for plant breeding programmes. Sweetpotato (Ipomoea batatas (L.) Lam.) genotypes frequently exhibits extensive variations in terms of its morphological characteristics. A field experiment was carried out at National Root Crops Research Institute, Umudike, Abia State, Nigeria during 2015 and 2016, to characterize morphological diversity among population of 38 first filial generation $\left(F_{1}\right)$ sweetpotato genotypes derived from seeds generated through controlled cross systems from International Potato Center, Kumasi, Ghana, comprised of three different sweetpotato families (LigriXFaara, LigriXApomoden and LigriXSauti), including two local check varieties (UMUSPO3 and TIS87/0087). Morphological traits for the sweetpotato genotypes were scored using a descriptor manual at 90 days after planting for the shoot morphology and at 120 days after planting for root morphology. Twenty characters were introduced into Statistical Package for Social Scientists software (Version 22) for cluster analysis which done on all the 20 characters, based on Euclidean distance and similarity matrix and a dendrogram generated using the ward's method. Most of the genotypes had pink skin colour and creamy flesh colour. Cluster analysis revealed that all the genotypes were grouped into four different classes based on their morphological traits. The results of this study revealed a suitable breeding strategy for superior $\mathrm{F}_{1}$ genotypes for yield. This would provide a large gene pool for effective recombination to raise promising sweetpotato variety of considerable agricultural importance.
\end{abstract}

Keywords: Morphological traits, Phenotypic characterization, Storage root, Sweetpotato, Variation.

\section{INTRODUCTION}

Sweetpotato (Ipomoea batatas (L.) Lam) is a crop of tropical American origin and it is a member of the botanical family Convolvulaceae [1]. Sweetpotato is rated as the second important root crop after cassava in many countries within the Sub-Saharan Africa region [2]. This crop is predominantly cultivated within and across different confinements, namely; Africa, Asia, Latin America and 52\% of the total world production of the crop grown is obtained from China [3]. The crop is principally utilized as food for human consumption, consequently, the crop has a robust dietary benefits [4]. Sweetpotato is a crop that adapts to different soil types and it takes 
about three to five months before it attain harvest maturity, depending on prevailing environmental conditions and the genotypes cultivated [5]. Sweetpotato is a stable food that is consumed by human, serves as feed for livestock, raw materials for industrial processes and as an alternative source of fuel [6].

Sweetpotato is a crop that sustains the ability to demonstrate extensive variations that is observable in terms of its plant architecture, showing diverse morphological traits with varying levels of yield potential, storage root size, shape, flesh and skin colour of storage roots as well as vine colour, shapes of leaves and branches [7]. Sweetpotato genotypes are self-incompatible, owing to its obligate outcrossing nature and have high levels of heterozygosity [7].

Characterization of the phenotypic characters of sweetpotato genotypes is a necessary requirement in evaluating its diversity and is achieved using descriptors. With the aid of descriptors, it is possible, affordable and less demanding to measure, evaluate and document phenotypic characters or traits [8]. Descriptors provides discrimination in terms of the phenotypic and morphological description of the plant [8]. Phenotypic traits, however, are commonly influenced by environmental factors [9]. Among other uses, phenotypic characterization has proven to be advantageous in duplicates identification, genetic diversity studies as well as correlation with characters of agronomic relevance [8].

Previous studies shown that variations among various crops have been successfully assessed in different parts of the world using morphological characterization [10]. This method of assessing diversity among crops is user-friendly, inexpensive and was considered to be the fundamental determinant of the agronomic value [11].

Currently, advances in breeding programs in Africa has led to the development of diverse genotypes of sweetpotato. There is paucity of information regarding their diversity, hence, there is need for proper evaluation, identification and documentation of diversity of new progenies which are products of hybridization programs. Therefore, the objective of this study was to characterize the phenotypical diversity of sweetpotato hybrids obtained from controlled cross system.

\section{MATERIALS AND METHODS}

\subsection{Study site}

The experiment was conducted during the 2015 and 2016 planting seasons at the National Root Crops Research Institute, Umudike, Southeast Nigeria. Umudike is located at latitude $05^{\circ} 29^{\prime} \mathrm{N}$, longitude $07^{\circ} 33^{\prime} \mathrm{E}$, and at an altitude $122 \mathrm{~m}$ above sea level. Umudike is in the humid tropics and has a total rainfall of about $2177 \mathrm{~mm}$ per annum, annual average temperature of about $26^{\circ} \mathrm{C}$ and its soil is classified as sandyloam utisol [12]. 
Vol. 06, No. 06; 2021

ISSN: $2456-8643$

Table 1: Families of the sweetpotato seed, source and number seedlings used for the study

\begin{tabular}{|llll|}
\hline S/No. & Parents & Source & No. of seedlings \\
\hline 1. & LigriXFaara & CIP, Kumasa, Ghana & 18 \\
2. & LigriXApomoden & CIP, Kumasa, Ghana & 9 \\
3. & LigriXSauti & CIP, Kumasa, Ghana & 11 \\
4. & Umuspo3 (Check variety) & NRCRI, Umudike, Nigeria & \\
5. & TIS 87/0087 (Check variety) & NRCRI, Umudike, Nigeria & \\
\hline
\end{tabular}

\subsection{Nursery Management}

The soil of the nursery comprised a mixture of topsoil, organic matter and river sand at the ratio of 3:2:1 respectively. The nursery was prepared in the greenhouse of National Root Crops Research Institute, Umudike, Southeast, Nigeria using polythene bags containing $1 \mathrm{~kg}$ of soil. After soaking the seeds for about twenty four hours in cold water to break dormancy, it was discovered that some of the seeds sprouted. The seeds were carefully isolated from the container of cold water and sown individually into the well-watered soil contained in polythene bags.

\subsection{Land preparation and experimental design}

The land for the experimental site was cleared, ploughed, harrowed and ridged. The prepared land was marked out into plots of $1.5 \mathrm{~m}^{2}(1 \mathrm{mx} 1.5 \mathrm{~m})$. The field was laid out in an augmented design with three replications and two check varieties were panted at intervals. The planting distance was $1 \mathrm{mx} 0.3 \mathrm{~m}$. This gave five stands of sweetpotato per plot which is equivalent to 33,333 stands per hectare. Therefore, the land area for this research was $180 \mathrm{~m}^{2}$. Planting was done on $21^{\text {th }}$ July, 2015 and $18^{\text {th }}$ April, 2016 using five vines on each plot. The plants were rainfed. Weeding was done at 6 and 12WAP. Compound fertilizer (NPK 15:15:15) was applied at the rate of $400 \mathrm{~kg} / \mathrm{ha} 4$ weeks after planting (WAP) using side placement.

\subsection{Evaluation of Morphological Traits}

Twenty morphological traits for the sweetpotato descriptors were scored using a scale of zero to nine [13] at 90-120 days after planting (DAP). These traits can be grouped into foliar morphology (90-100 DAP) and storage root (120 DAP) descriptors. Characterization was achieved using standard descriptors; morphological and agronomical descriptors developed by 'Centro Internacional de la papa' (CIP) [14] as shown on Tables 2. Quantitative measurements were taken for internode length, internode diameter, leaf area, leaf size (length from the base to the tip of the leaf) to know the differences in their development. Morphological character states related to length and size were scored on the basis of the average value of measurements made on several plants of each genotype. The petiole length, internode length, matured leaf size (distance from the tip to the base) of the leaf were measured using a meter rule. The internode diameter was measured using an electronic calliper (G02022 165). Leaf area measurements were done using a leaf area measuring system (Delta T devices. Model RS232). The characters of vines and leaves were recorded from the section located in the middle portion of the stem. 


\subsection{Data Analysis}

Frequency distribution of aerial and root storage morphological traits were analysed used doughnut charts and cluster analysis was performed for all morphological characters, based on Euclidean distance and similarity matrix was determined using Euclidean distance and a dendrogram generated using the ward's method [15].

Table 2: Morphological traits measured among sweetpotato (Ipomoea batatas) genotypes.

\begin{tabular}{|c|c|c|}
\hline $\begin{array}{l}\text { Trait } \\
\text { acronym }\end{array}$ & $\begin{array}{l}\text { Trait/ } \\
\text { descriptor }\end{array}$ & Score code - descriptor state \\
\hline PT & Plant type & $\begin{array}{l}\text { 3-erect }(<75 \mathrm{~cm}) ; 5 \text {-semi-erect }(75-150 \mathrm{~cm}) ; 7 \text {-spreading }(151-250 \\
\mathrm{cm}) ; 9 \text {-extremely spreading }(>250 \mathrm{~cm})\end{array}$ \\
\hline $\mathrm{GC}$ & Ground cover & $\begin{array}{l}\text { 3-low }(<50 \%) ; 5 \text {-medium (50-74\%); 7-high (75-90\%); 9-total } \\
(>90 \%)\end{array}$ \\
\hline VIL & $\begin{array}{l}\text { Vine internode } \\
\text { length }\end{array}$ & $\begin{array}{l}\text { 1-very short }(<3 \mathrm{~cm}) ; 3 \text {-short }(3-5 \mathrm{~cm}) ; 5 \text {-intermediate }(6-9 \mathrm{~cm}) ; 7- \\
\text { long }(10-12 \mathrm{~cm}) ; 9-\text { very long }(>12 \mathrm{~cm})\end{array}$ \\
\hline PVC & $\begin{array}{l}\text { Predominant } \\
\text { vine colour }\end{array}$ & $\begin{array}{l}\text { 1-green; } 2 \text {-green with few purple spots; } 3 \text {-green with many purple } \\
\text { spots; 4-green with many dark purple spots; } 5 \text {-mostly purple; } 6 \\
\text { mostly dark purple; } 7 \text {-totally purple; } 8 \text {-totally dark purple }\end{array}$ \\
\hline SVC & $\begin{array}{l}\text { Secondary vine } \\
\text { colour }\end{array}$ & $\begin{array}{l}\text { 0-absent; } 1 \text {-green base; } 2 \text {-green tip; } 3 \text {-green nodes; } 4 \text {-purple base; } 5 \\
\text { - purple tip; 6-purple nodes }\end{array}$ \\
\hline GOL & $\begin{array}{l}\text { General outline } \\
\text { of the leaf }\end{array}$ & $\begin{array}{l}\text { 1-rounded; 2-reniform; 3-cordate; 4-triangular; 5-hastate; 6-lobed; } \\
\text { 7-almost divided }\end{array}$ \\
\hline LLT & Leaf lobes type & $\begin{array}{l}0 \text {-no lateral lobes; 1-very slight; 3-slight; 5-moderate; 7-deep; } 9 \text { - } \\
\text { very deep }\end{array}$ \\
\hline LLN & $\begin{array}{l}\text { Leaf } \\
\text { number }\end{array}$ & Direct measurement $(1,3,5,7,9)$ \\
\hline SCLL & $\begin{array}{l}\text { Shape of central } \\
\text { leaf lobe }\end{array}$ & $\begin{array}{l}\text { 0-absent; 1-toothed; 2-triangular; 3-semi-circular; 4-semi-elliptic; } \\
\text { 5-elliptic; 6-lanceolate; 7-oblanceolate; 8-linear (broad); 9-linear } \\
\text { (narrow) }\end{array}$ \\
\hline MLC & $\begin{array}{l}\text { Mature } \\
\text { colour }\end{array}$ & $\begin{array}{l}\text { 1-yellow-green; 2-green; 3-green with purple edge; 4-greyish- } \\
\text { green; 5-green with purple veins on upper surface; 6-slightly purple; } \\
\text { 7-mostly purple; 8-green upper, purple lower; 9-purple both } \\
\text { surfaces }\end{array}$ \\
\hline ILC & $\begin{array}{l}\text { Immature leaf } \\
\text { colour }\end{array}$ & $\begin{array}{l}\text { 1-yellow-green; 2-green; 3-green with purple edge; 4-greyish- } \\
\text { green; 5-green with purple veins on upper surface; 6-slightly purple; } \\
\text { 7-mostly purple; 8-green upper, purple lower; 9-purple both } \\
\text { surfaces }\end{array}$ \\
\hline PL & Petiole length & $\begin{array}{l}\text { 1-very short }(<10 \mathrm{~cm}) ; 3 \text {-short }(10-20 \mathrm{~cm}) ; 5 \text {-intermediate }(21-30 \\
\mathrm{cm}) ; 7 \text {-long }(31-40 \mathrm{~cm}) \text {; very long }(>40 \mathrm{~cm})\end{array}$ \\
\hline PP & $\begin{array}{l}\text { Petiole } \\
\text { pigmentation }\end{array}$ & $\begin{array}{l}\text { 1-green; 2-green with purple near stem; 3-green with purple near } \\
\text { leaf; 4-green with purple at both ends; } 5 \text {-green with purple spots } \\
\text { throughout petiole; 6-green with purple stripes; } 7 \text {-purple with green } \\
\text { near leaf; } 8 \text {-some petiole purple, others green; } 9 \text {-totally or mostly }\end{array}$ \\
\hline
\end{tabular}




\begin{tabular}{|c|c|c|}
\hline & & purple \\
\hline SRS & $\begin{array}{l}\text { Storage root } \\
\text { shape }\end{array}$ & $\begin{array}{l}\text { 1-round; 2-round elliptic; 3-elliptic; 4-ovate; 5- obovate; 6-oblong; } \\
\text { 7-long oblong; 8-long elliptic; 9-long irregular }\end{array}$ \\
\hline PSC & $\begin{array}{l}\text { Predominant } \\
\text { skin colour }\end{array}$ & $\begin{array}{l}\text { 1-white; 2-cream; 3-yellow; 4-orange; 5-brownish orange; 6-pink; } \\
\text { 7-red; 8-purple red; 9-dark purple }\end{array}$ \\
\hline PFC & $\begin{array}{l}\text { Predominant } \\
\text { flesh colour }\end{array}$ & $\begin{array}{l}\text { 1-white; 2-cream; 3-dark cream; 4-pale yellow; 5-dark yellow; 6- } \\
\text { pale orange; 7-intermediate orange; 8-dark orange; 9-strongly } \\
\text { pigmented with anthocyanin }\end{array}$ \\
\hline $\mathrm{SFC}$ & $\begin{array}{l}\text { Secondary flesh } \\
\text { colour }\end{array}$ & $\begin{array}{l}\text { 0-absent; 1-white; 2-cream; 3-yellow; 4-orange; 5-pink; 6-red; 7- } \\
\text { purple-red; 8-purple; 9-dark purple }\end{array}$ \\
\hline VSRS & $\begin{array}{l}\text { Variability } \text { of } \\
\text { storage root } \\
\text { shape }\end{array}$ & 3-Uniform; 5-slightly variable; 7-moderately variable \\
\hline VSRS & $\begin{array}{l}\text { Variability of } \\
\text { storage root size }\end{array}$ & 3-Uniform; 5-slightly variable; 7-moderately variable \\
\hline
\end{tabular}

The traits and measurement methods were based on the International Board for Plant Genetic Resources descriptor list, CIP code [13]

\section{RESULTS}

Critical to the success of breeding program is the need to evaluate genetic variation of a particular crop. Morphological characterization has been used for various purposes including identification of duplicates, variability patterns and correlation with characteristics of agronomic importance [16]. The sweetpotato genotypes from CIP exhibited high morphological variability for the shoot and storage root characters which have been summarized in Figure 1, 2 and 3.

\subsection{Morphological Variation}

Plant type: the frequency distribution for the plant type indicated that majority of the progenies belonged to spreading (33\%), whereas $29 \%$ belonged to semi-erect type. The extremely spreading and erect habits were found to be low (18\%) and (20\%) respectively.

Vine internode length: The frequency distribution of the vine internode length indicated that majority of the full sib progenies belonged to the short type (47\%), the very short and intermediate were found to be $35 \%$ and $18 \%$ respectively, while the long type was found to be completely absent among the progenies.

Vine colour: High variability was observed in vine colour ranging from green to purple. It was observed that the progenies possessed predominantly purple colour (72\%). The other vine colours observed in the progenies were green with many dark purple spots $(10 \%)$, green with few purple spot $(6 \%)$, mostly purple $(5 \%)$, mostly dark purple $(5 \%)$, total purple $(1 \%)$ and totally dark purple $(1 \%)$ colouration.

Vine tip pubescence: vine tip pubescence was observed to vary ranging from absent to heavy. It was observed that the progenies recorded (52\%) for sparse pubescence, (26\%) for moderate pubescence, $(16 \%)$ for absent pubescence and $(6 \%)$ was observed for heavy pubescence. 
Vol. 06, No. 06; 2021

ISSN: $2456-8643$

General outline of the leaves: Sweetpotato leaves are reported to be variable in size and shape even within the same plant. The frequency distribution of the general outline of the leaves of the progenies showed that lobed type had the maximum frequency (66\%). This was followed by triangular (16\%), Haste (7\%), Almost divided (6\%), while the occurrence of the cordate leaf type was lowest (5\%).

Shape of the central leaf lobe: the shape of the central leaf lobe showed that eight key characters were identified among the progenies namely, toothed, triangular, semi-circular, semi-elliptic, elliptic, lanceolate, oblanceolate, and linear (narrow). The frequency distribution of the progenies showed that elliptic (26\%) was the prevalent type, which was followed by semi-elliptic (21\%). The frequency of other shapes of the central leaf lobe was toothed (15\%), lanceolate $(13 \%)$, triangular (10\%), oblanceolate (8\%), and linear (5\%), while semi-circular had the lowest (2\%).

Storage root shape: the prevalent storage root shape was round (37\%) and (48\%) for both full sib and half sib progenies respectively, followed by elliptic (22\%) and (28\%) respectively.

Predominant skin colour: the progenies possessed a variety of tuber skin colour varying from white, cream, orange, brownish orange and pink. Pink colour was predominant (58\%), followed by cream colour (34\%). Orange colour and brownish-orange colour (3\%) and white colour was totally absent $(0 \%)$.

Predominant flesh colour: Attractive flesh colours were exhibited progenies such as white, cream, yellow, pale yellow, pale orange, intermediate orange and dark orange. The frequency distribution showed that cream colour was prevalent among the full sib $(65 \%)$. Others include; white colour $(15 \%)$, intermediate orange colour $(12 \%)$, pale yellow colour $(6 \%)$, dark orange colour $(2 \%)$ while pale orange colour was absent $(0 \%)$. 

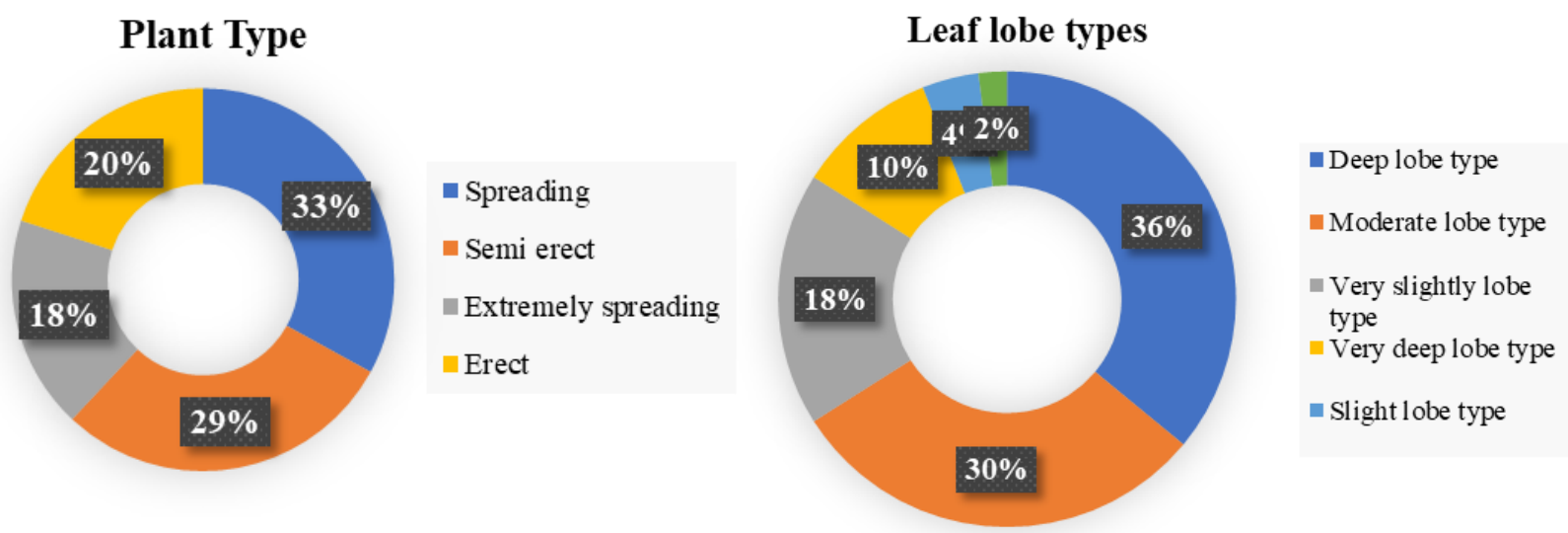

Predominant vine colour
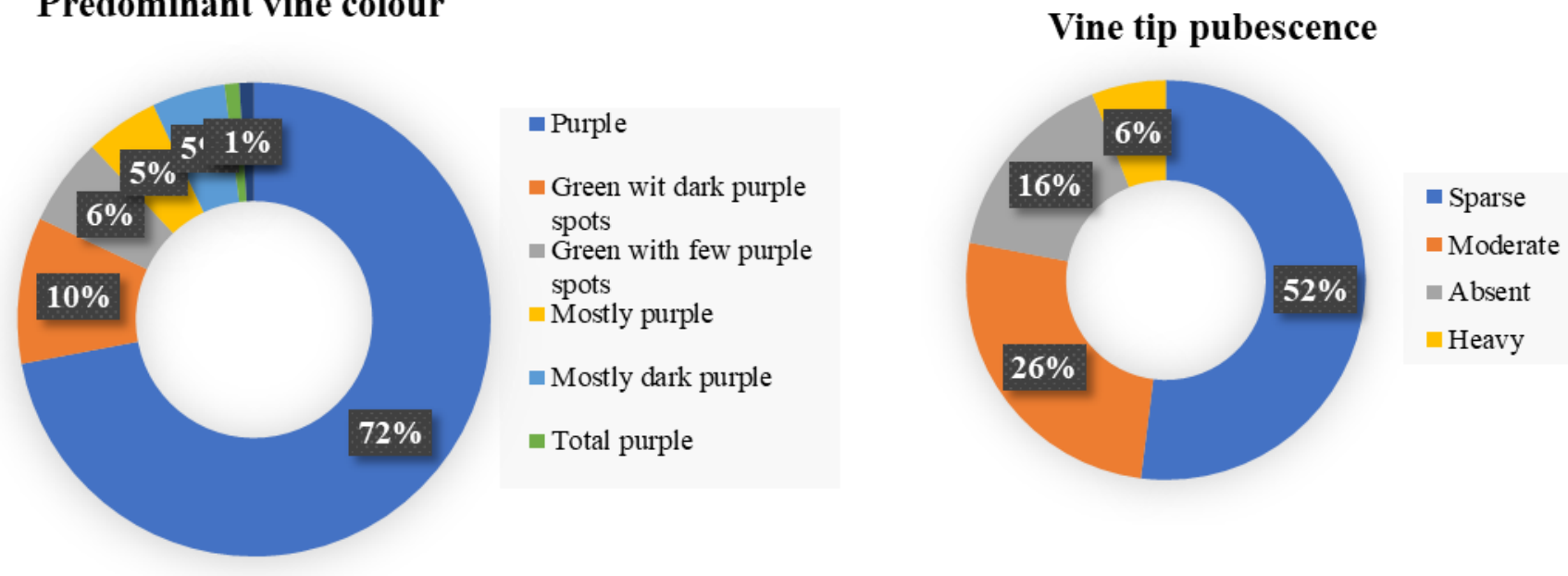

Leaf lobe number
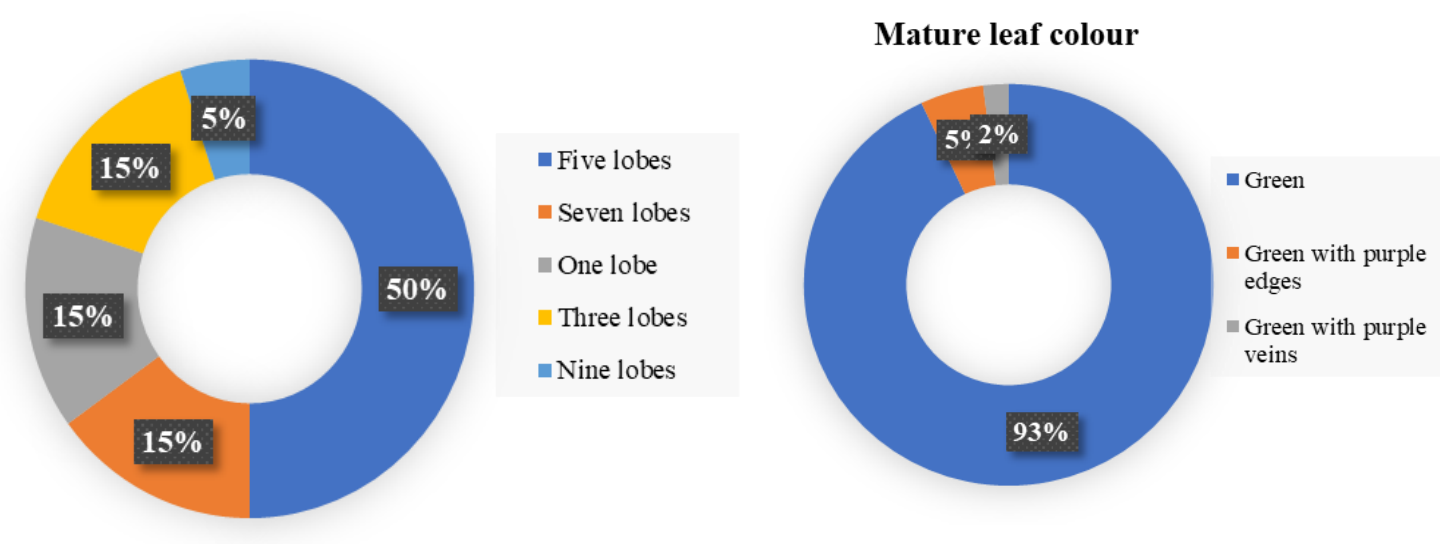

Figure 1: Morphological shoot characters evaluated using descriptors in 38 progenies of sweetpotato represented in doughnut charts 

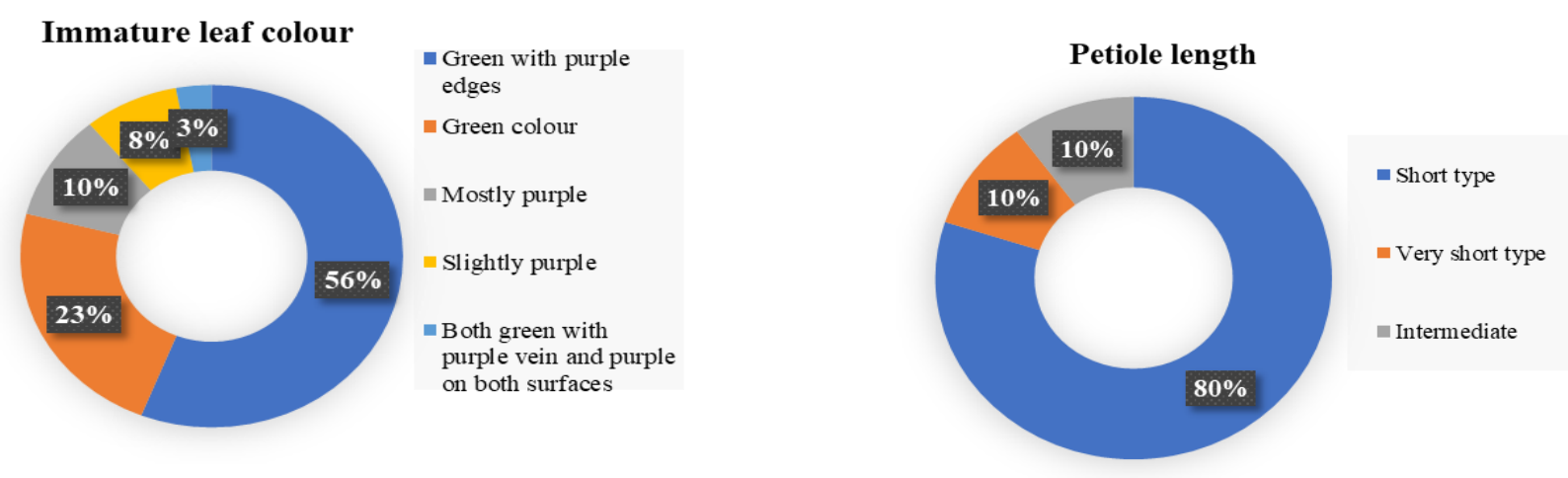

Storage root shape

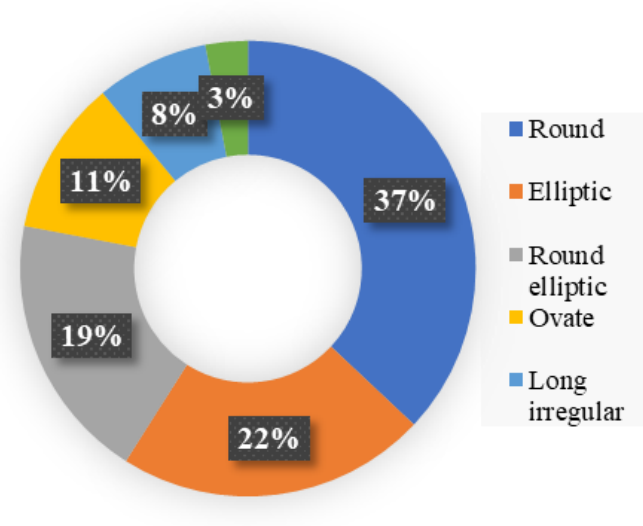

\section{Predominant skin colour}
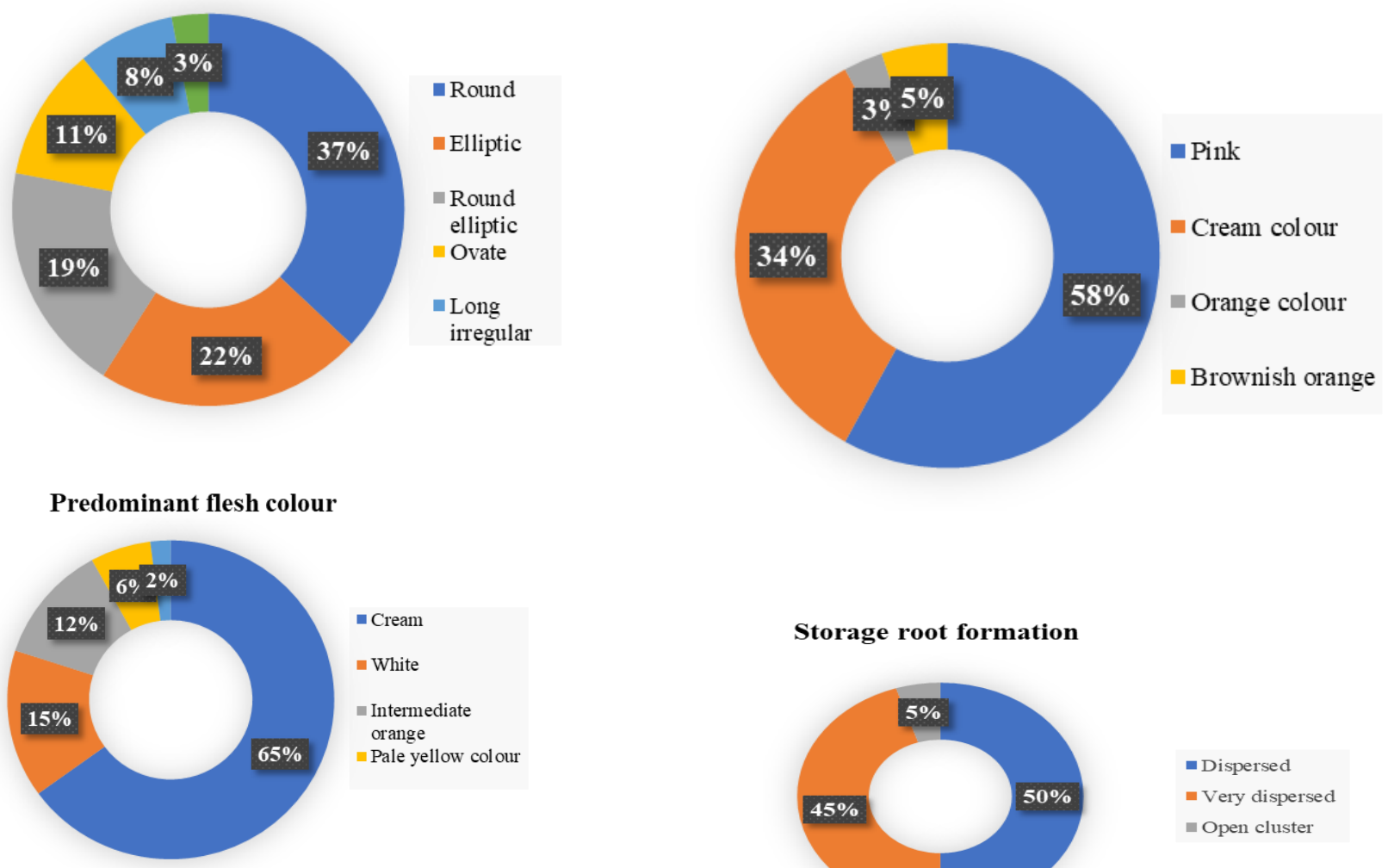

Figure 2: Morphological shoot characters evaluated using descriptors in 38 progenies of sweetpotato represented in doughnut charts 
Vol. 06, No. 06; 2021

ISSN: $2456-8643$

\section{Cluster Analysis of 40 Sweetpotato Progenies}

In this study, the cluster analysis grouped the 40 progenies into four major clusters. A dendrogram constructed using ward's method separated the 40 sweetpotato progenies into four major clusters at different similarity levels ranging from 25 to 1 (Fig. 3). At 10 similarity level, four major clusters was observed (Fig.3).

Cluster Group I consisted of fourteen progenies, plant type was spreading $(151-250 \mathrm{~cm})$, ground cover was high (75-90\%), vine internode diameter was very thick (>12mm), vine tip pubescence was moderate, general outline of the leaf was lobed, mature leaf colour was green, petiole pigmentation was green with purple at both ends, storage root shape was round, predominant skin colour was pink, predominant flesh colour was white, storage root formation was open cluster.

Cluster Group II consisted four progenies, plant type was erect $(<75 \mathrm{~cm})$, ground cover was low $(<50 \%)$, vine internode length was short $(3-5 \mathrm{~cm})$, vine internode diameter was very thick $(>12 \mathrm{~mm})$, vine tip pubescence was heavy, general outline of the leaf was lobed, mature leaf colour was green, storage root shape was round, predominant skin colour was pink, predominant flesh colour was pale orange.

Cluster Group III consisted twelve progenies, plant type was spreading $(151-250 \mathrm{~cm})$, ground cover was high $(75-90 \%)$, vine internode diameter was very thick $(>12 \mathrm{~mm})$, vine tip pubescence was sparse, general outline of the leaf was triangular, mature leaf colour was green, petiole pigmentation was green with purple at both ends, storage root shape was round, predominant skin colour was pale cream, predominant flesh colour was cream, storage root formation was open cluster.

Cluster Group IV consisted of four progenies, plant type was spreading $(151-250 \mathrm{~cm})$, ground cover was high (75-90\%), vine internode diameter was very thick $(>12 \mathrm{~mm})$, vine tip pubescence was moderate, general outline of the leaf was lobed, leaf lobe type was deep, leaf lobe number was five, mature leaf colour was green, petiole pigmentation was green with purple at both ends, storage root shape was round elliptic, predominant skin colour was pink, predominant flesh colour was white, storage root formation was open cluster.

Table 2: Cluster groups of the sweetpotato progenies based on shoot and root morphological variations

\begin{tabular}{|lll|}
\hline $\begin{array}{l}\text { Cluster } \\
\text { groups }\end{array}$ & $\begin{array}{l}\text { No. } \\
\text { progenies }\end{array}$ & Progenies \\
\hline I & 14 & LigriXFaara/11, LigriXFaara/17, LigriXFaara/13, LigriXSauti/5, \\
& & LigriXSauti/7, LigriXApomoden/7, LigriXFaara/5, LigriXFaara/15, \\
& & LigriXFaara/10, LigriXFaara/16, LigriXFaara/8, LigriXApomoden/6, \\
& & LigriXFaara/4, LigriXSauti/3. \\
II & 4 & LigriXApomoden/3, LigriXApomoden/8, TIS 87/0087, Umuspo 3 \\
III & 12 & LigriXFaara/9, LigriXFaara/14, LigriXApomoden/5, LigriXFaara/1, \\
\hline
\end{tabular}


International Journal of Agriculture, Environment and Bioresearch

Vol. 06, No. 06; 2021

ISSN: $2456-8643$

\begin{tabular}{|c|c|c|c|c|c|}
\hline & & $\begin{array}{l}\text { LigriXFaara/7, Ligr } \\
\text { LigriXSauti/1 }\end{array}$ & Faara/2, LigriXSaut & LigriXSauti/6, & LigriXSauti/4, \\
\hline IV & 5 & $\begin{array}{l}\text { LigriXApomoden/1, } \\
\text { LigriXApomoden/4 }\end{array}$ & LigriXApomoden/2, & LigriXFaara/6, & LigriXSauti/8, \\
\hline
\end{tabular}

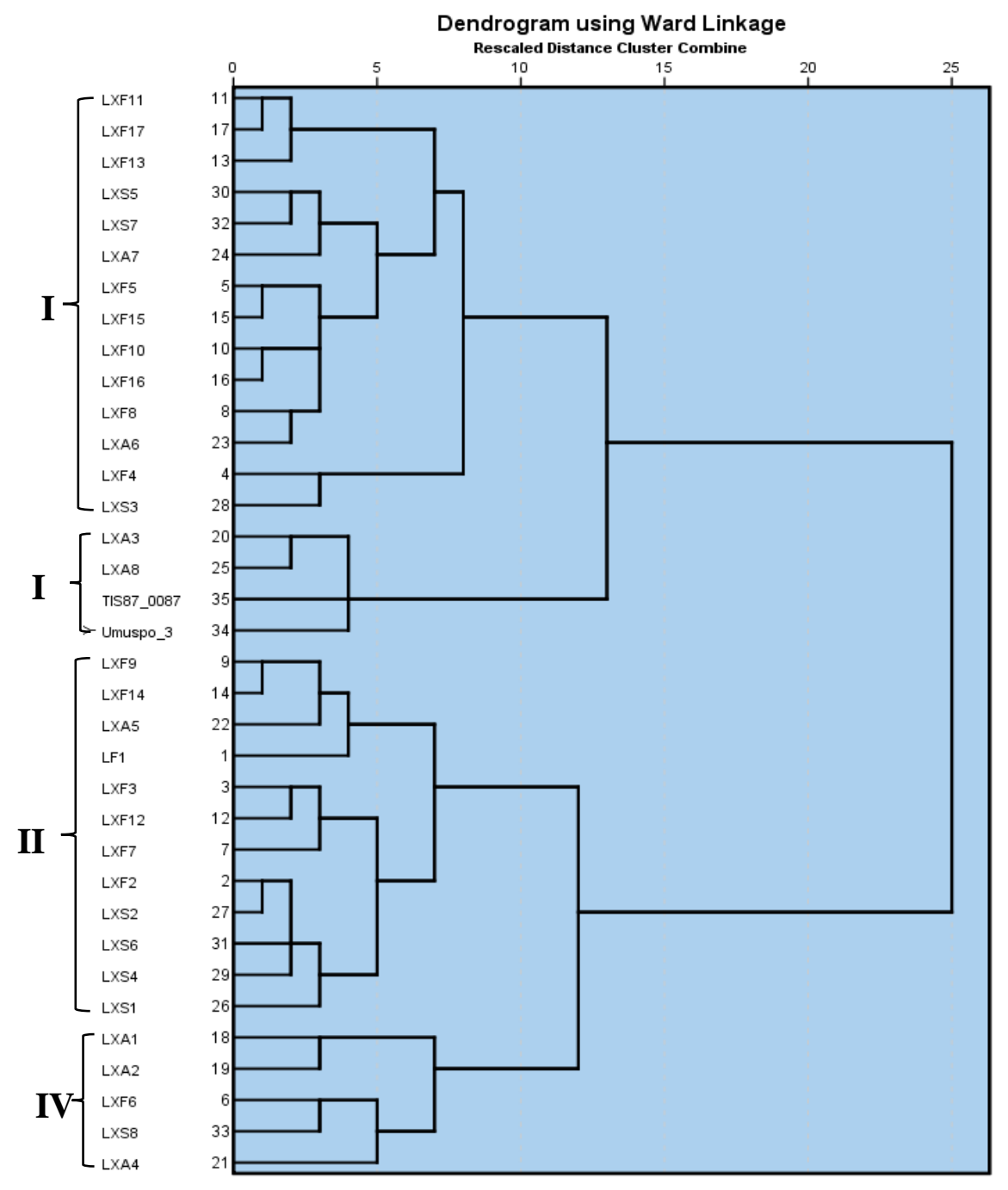

Figure 3: Dendrogram showing main clusters of 40 sweetpotato genotypes revealed by Ward's linkage based on the twenty discriminant phenotypic characters. 
Vol. 06, No. 06; 2021

ISSN: $2456-8643$

\section{DISCUSSION}

A high level of diversity occurs among the sweetpotato cultivars for the morphological as well as root characters. They differ in the shape of roots, depth of rooting, and several other vegetative characters. The possibility of improvement in any crop is dependent on the variability available in the crop, higher the genetic variability in the traits, better the chances of improvement through selection [17]. In sweetpotato, the skin as well as the flesh contains carotenoids and anthocyanin pigments which determines its colour. The combination and intensity of these pigments vary to produce varying intensities of cream, yellow, orange, pink or purple skin and flesh colour [18]. Previous reports on characterization of morphological diversity in sweetpotato have been restricted to germplasm bank collections which revealed high phenotypical variability [19]. Similar results were observed in another study by [20] while evaluating the morphological characters of 250 hybrid progenies of sweetpotato generated from a controlled cross system. All these studies showed that no clear cut demarcation was visible for any of the morphological traits and all the characters showed continuous variation [21]. From evaluating 14 sweetpotato accessions, [22] observed high morphological variability, concluding that the most informative descriptors were the vine tip pubescence, the abaxial leaf vein pigmentation and the shape of the roots. The traits that most contributed to the diversity were distribution of root flesh color, root shape, storage root surface defects and predominant storage root flesh color. The existence of continuous and overlapping variation points towards the quantitative nature of all the characters studied [23]. [24] as well as [25] observed variability in several growth habits in sweetpotato and reported that growth habit has a direct effect on the growth and yield of companion crops, soil characteristics, weeds control and may also aid in the selection of sweetpotato in cropping systems.

[26] revealed that cluster analysis of 19 sweetpotato genotypes using 26 characters observed that three major groups occurred with a similarity index ranging from 0.42 to 1.00 before maturity and 0.34 to 1.00 at maturity based on Euclidean distance. [27] observed two major groups with a low genetic similarity of 0.52 in a cluster analysis of Tanzanian elite sweetpotato genotypes for resistance to sweetpotato virus disease and high dry matter content. In addition, significant differences between genotypes and genetic distance ranging from 0.26 to 0.80 were identified during morphological characterization of eight genotypes of Solanum retroflexum [28]. An understanding into the morphological diversity between genotypes is essential for crop breeding [29]. Plant breeding programs require sufficient genetic variation for designed crosses and create new genetic recombinants.

\section{ACKNOWLEDGMENT}

The first author thanks Prof Peter I. O. for providing thorough supervision through this study. The first author also thanks Dr Afuape S. O. (the second author) for sourcing the plant materials and support during this research. Mr. Ulasi Eugene and Mrs. Ulasi Patricia are thanked immensely for their financial support during this research.

\section{CONCLUSION}

This study has provided preliminary morphological and agronomic characterization of the different progenies of sweetpotato parents obtained a controlled cross system. Morphological characterization of the sweetpotato genotypes revealed significant variations in the vine, leaf, 
Vol. 06, No. 06; 2021

ISSN: $2456-8643$

storage root and floral characters. In this present study, the sweetpotato population therefore represents a rich diversity that can form a good basis for selection in relation to genetic advancement.

\section{REFERENCES}

[1] Allemann, J., Laurie, S. M., Thiart and Vorster H. J. (2004). Sustainable production of root and tuber crops (potato, sweetpotato, indigenous potato, cassava) in Southern Africa. South African Journal of Botany, 70:60-66.

[2] FAOSTAT. (2006). Food and Agriculture Organization of the United Nations Database. Food and Agriculture Organization of the United Nations. Available at http://faostat.fao.org/site/612/default.aspx\#ancor

[3] FAOSTAT. (2009). Food and Agriculture Organization of the United Nations Database. Food and Agriculture Organization of the United Nations. Available at http://faostat.fao.org/site/612/default.aspx\#ancor

[4] Gibson, R. W. and Aritua, V. (2002). The perspective of sweetpotato chrolotic Stunt virus in sweetpotato production in Africa: A review. African Crop Science Journal, 10(4): 281-310.

[5] Afuape SO, Okocha PI, Njoku D. 2011. Multivariate assessment of the agromorphological variability and yield components among sweetpotato (Ipomoea batatas (L.) Lam) landraces. African Journal of Plant Science 5: 123-132.

[6] Thottappilly, G. and Loebenstein G. (2009). Introductory remarks. In The Sweetpotato. G. Thottappilly and Loebenstein G. (eds). Springer Science+ Business Media B. V. 2009. Springer, New York.

[7] Zhang, D.P., D. Carbajulca, L. Ojeda, G. Rossel, S. Milla, C. Herrera and M. Ghislain. (2000). Microsatellite Analysis of Genetic Diversity in Sweetpotato Varieties from Latin America. CIP Program Report 1999 - 2000:295-301.

[8] CIAT. (2007). Germplasm characterization. Multi-Institutional distance learning course on the ex-situ conservation of plant genetic resources. (eds). 171-184 pp. In: Pineda B. and Hidalgo R.

[9] Elameen A, Larsen A, Klemsdal S, Fjellheim S, Sundheim L, Msolla S, Masumba E, Rognli O (2011). Phenotypic diversity of plant morphological and root descriptor traits within a sweetpotato germplasm collection from Tanzania. Genet. Resourc. Crop Evol. 58:397-407

[10] Bos HJ, Vos J, Strulk PC (2000). Morphological analysis of plant density effects on early leaf area growth in maize. Netherlands J. Agric.Sci.48:199-212.

[11] Li, P., Wang, Y., Sun, X. and Han J (2009). Using microsatellite (SSR) and morphological markers to assess the genetic diversity of 12 falcata (Medicagosativaspp. falcata) populations from Eurasia. Afr. J. Biotechnol. 8(10):2102-2108.

[12] National Root Crops Research Institute (2012). Annual Report of the National Root Crops Research Institute, Umudike. 
Vol. 06, No. 06; 2021

ISSN: $2456-8643$

[13] CIP (1999). Annual report. International Potato Centre, Lima, Peru. International potato centre (CIP), Asian vegetable research and development centre (AVRDC), International board for plant genetic resources (IBPGR), 1991. Descriptors for Sweetpotato. (ed.) Huaman, Z. IBPGR, Rome, Italy. pp. 43-130.

[14] Huaman, Z. (1992). Descriptor for sweetpotato. International Board for Plant Genetic Resources (CIP/AVRDC/IBPGR), Rome, Italy.133p.

[15] Mohammadi, S. A. and Prasanna B. M. (2003). Analysis of genetic diversity in crop plant-salient statisticial tools and consideration. Crop Science 43: 1235-1248 Molecular Breeding 11:169-185.

[16] CIAT, 1993. Biotechnology Research Unit. Annual Report, Cali, Colombia.

[17] Jindal, S.K., Arora, D. and Ghai, T.R. (2010). Variability studies for yield and its contributing traits in okra. Electronic Journal of Plant Breeding. 1(6): 1495-1499.

[18] Binu H.., Vimala, B. and Mohan, C. (2011). Efficient DNA isolation and electrophoretic methods for molecular analysis of sweetpotato. Gene Conserve, 10(40): 87-109.

[19] Ritschell, P.S. and Huaman, Z. (2002). Variabilidade morfologica da coleçao de germoplasma de batata-doce da Embrapa-Centro Nacional de Pesquisa de Hortaliças. Pesquisa Agropecuaria Brasileira. 37. 485-492.

[20] Vimala, B. and Binu H. 2011. Variability of morphological characters and dry matter content in the hybrid progenies of sweetpotato (Ipomoea batatas (L.) Lam). Gene Conserve. 10/39. 65-86.

[21] Vimala, B. and Leksmi, K.R. 1990 Heritability estimates in sweetpotato. Journal of Root Crops. 17. 35-38.

[23] Vimala, B., Nair, R.B. 1988. Segregation pattern of some morphological characters in the hybrid progenies of sweetpotato (Ipomoea batatas L.). Journal of Root Crops. 14. 63-65.

[24] Antiaobong, E. E., \& Bassey, E. E. (2008). Constraints and prospects of sweetpotato (Ipomoea batatas (L) Lam.) production in the humid environment of Southeastern Nigeria. Proceedings of the Second African Regional Conference on sustainable development, held at the Governor's Office Annex, Uyo, Nigeria, 2(3), 68-72.

[25] Korieocha, D. S., Ogbonna, M. C., Nwokocha, C. C., Echendu, T. N. C., \& Okorocha, E. O. A. (2009). Effect of time of herbicide application and sweetpotato morpho-types on the effectiveness of herbicide on weeds (pp.12-16). Proceedings of the 43rd Annual Conference of Agricultural Society of Nigeria. Held at National Universities Commission, Abuja, Tuesday 20th-Friday 23rd October.

[26] Fongod AGN, Mih AM, Nkwatoh TN. 2012. Morphological and agronomical characterization of different accessions of sweetpotatoe (Ipomoea batatas) in Cameroon. International Research Journal of Agricultural Science and Soil Science 2: 234-245.

[27] Tairo F, Mneney E, Kullaya A. 2008. Morphological and agronomical characterization of sweetpotato [Ipomoea batatas (L.) Lam.] germplasm collection from Tanzania. African Journal of Plant Science 2: 77-85. 
International Journal of Agriculture, Environment and Bioresearch

Vol. 06, No. 06; 2021

ISSN: $2456-8643$

[28] Jacoby A, Labuschagne M. T, Viljoen CD. (2003). Genetic relationships between southern African Solanum retroflexum Dun. and other related species measured by morphological and DNA markers. Euphytica 132: 109-113.

[29] Acquaah G. (2007). Principles of plant genetics and breeding. Oxford: Wiley-Blackwell. 